Special Issue (October)

Online - 2455-3891
Print - 0974-2441

$\underline{\text { Research Article }}$

\title{
THE RISKS OF USING TRANEXAMIC ACID AND VITAMIN K FOR DECREASING PROTHROMBIN TIME AND ACTIVATED PARTIAL THROMBOPLASTIN TIME VALUES IN INTRACRANIAL HEMORRHAGIC PATIENTS AT RUMAH SAKIT UMUM PUSAT FATMAWATI JAKARTA
}

\author{
SITI ZAMILATUL AZKIYAH ${ }^{1}$, SUDIBYO SUPARDI ${ }^{2}$, RETNOSARI ANDRAJATI ${ }^{1 *}$ \\ ${ }^{1}$ Department of Pharmaceutical Chemistry, Faculty of Pharmacy, Universitas Indonesia, Jakarta, Indonesia. ${ }^{2}$ National Institute of Health \\ Research Development, Ministry of Health, Republic of Indonesia, Jakarta, Indonesia. Email: retnosaria@gmail.com
}

Received: 21 April 2017, Revised and Accepted: 13 July 2017

ABSTRACT

Objective: Intracranial hemorrhaging is a life-threatening condition that requires intensive treatment. Such hemorrhaging can happen spontaneously and may be caused by vascular malformations, trauma, or the administration of anticoagulant medications. The purpose of this study was to evaluate the risks of using tranexamic acid and Vitamin K for decreasing prothrombin time (PT) and activated partial thromboplastin time (aPTT) values in intracranial hemorrhagic patients.

Methods: This study used a retrospective cohort design, and data were taken from patients' medical records at the medical record installation of Rumah Sakit Umum Pusat Fatmawati in Jakarta. A total of 125 medical records were selected based on the inclusion criteria. The first group included patients receiving only tranexamic acid, and the second group consisted of patients receiving both tranexamic acid and Vitamin K.

Results: Statistical analysis using Chi-squared testing for the first group showed a significant decrease in aPTT values, with $\mathrm{p}=0.000$ ( $\mathrm{p}<0.05$ ), but there was no significant decrease in PT values, with $\mathrm{p}=0.314(\mathrm{p}<0.05)$. Statistical analysis using Chi-squared testing in the second group showed a significant decrease in aPTT values, with $\mathrm{p}=0.000(\mathrm{p}<0.05)$, and a significant decrease in PT values, with $\mathrm{p}=0.034(\mathrm{p}<0.05)$. Patients that used tranexamic acid and Vitamin K decreased the PT and aPTT values 2.7 times and 1, 6 times greater than patients without tranexamic acid and Vitamin K. Patients that used tranexamic acid decreased the PT and aPTT values 2.5 times and 1.2 times greater than patients without tranexamic acid.

Conclusions: The combination of tranexamic acid and Vitamin $\mathrm{K}$ is potentially more effective in decreasing of hemorrhaging.

Keywords: Tranexamic acid, Vitamin K, Anticoagulant, Prothrombin time, Activated partial thromboplastin time.

(C) 2017 The Authors. Published by Innovare Academic Sciences PvtLtd. This is an open access article under the CC BY license (http://creativecommons. org/licenses/by/4. 0/) DOI: http://dx.doi.org/10.22159/ajpcr.2017.v10s5.23117

\section{INTRODUCTION}

Intracranial hemorrhaging is a life-threatening condition that requires intensive treatment. Such hemorrhaging can occur spontaneously and may be caused byvascular malformations, trauma, or the administration of anticoagulant medications. Intracranial hemorrhaging refers to hemorrhagic bleeding that occurs in the cranium, including intracerebral bleeding, subarachnoid bleeding, subdural bleeding, and epidural bleeding. There have been several studies assessing the parameters of hemostasis associated with these events. Some of them have examined prothrombin time (PT) or activated partial thromboplastin time (aPTT) [1-3].

A retrospective studies of the coagulogram data of intracerebral hemorrhagic patients demonstrated a relationship between PT and aPTT values, with intracerebral hemorrhagic patients having prolonged PT 2.4 times and prolonged aPTT 1.57 times [4,5]. About a third of patients suffering from brain injuries have been reported as having coagulation problems, which increases the risk of bleeding and high-mortality rates. The administration of tranexamic acid as an antifibrinolytic in patients with intracranial hemorrhaging may reduce the reoccurrence of bleeding but may potentially lead to cerebral ischemia, which could worsen the patient's condition. Currently, the use of tranexamic acid is often combined with Vitamin $\mathrm{K}$, but there is no clear evidence in the literature on the effectiveness of this combination compared to the single use of either tranexamic acid or Vitamin K. Therefore, this study was intended to determine the effects of using both tranexamic acid and Vitamin $\mathrm{K}$ on the coagulation profiles of hemorrhagic stroke patients.

\section{METHODS}

The preferred study design was a retrospective cohort study. Data were retrieved retrospectively from the medical records of intracranial hemorrhagic patients from January 2013 to December 2015. The inclusion criteria were patients aged 18 years old and older that were admitted with diagnosed intracranial hemorrhagic. The results were presented both descriptively and analytically. The sample included patients' medical records indicating intracranial hemorrhagic diagnoses at the inpatient ward installations of Rumah Sakit Umum Pusat Fatmawati that satisfied the inclusion criteria. The first group included patients receiving only tranexamic acid, and the second group consisted of patients receiving both tranexamic acid, and Vitamin K. The control group included patients who did not receive either tranexamic acid or Vitamin K. Statistical analysis was performed using the SPSS version 21.

\section{RESULTS}

In this study, the number of samples obtained was 125 . From the total number of samples, there were 82 male patients and 43 female patients. The samples included adult patients of ages 18 years and above. Based on age criteria, patients were divided into two groups, with the first group including those between 18 and 60 years old $(n=95)$ and the second including those more than 60 years old $(n=30)$. Relationship between tranexamic acid therapies is described in Tables 1-5. Further, the coagulation cascade scheme is represented in Fig. 1.

PT and aPTT Values of Intracranial Hemorrhagic Patients The mean value of aPTT among the intracranial hemorrhagic patients included in this study was 30.69 seconds, while the average aPTT value 


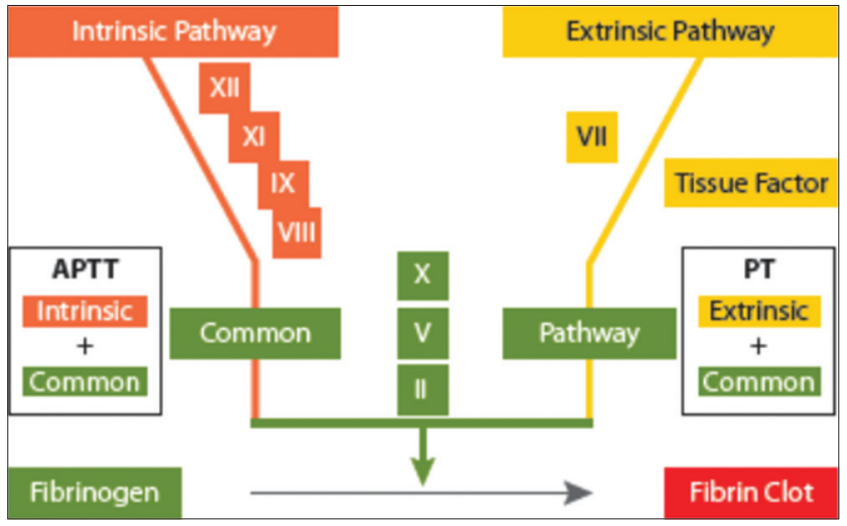

Fig. 1: Coagulation cascade scheme

Table 1: Relationship between tranexamic acid therapy and aPTT values among intracranial hemorrhagic patients at RSUP Fatmawati (January 2013-December 2015)

\begin{tabular}{llll}
\hline $\begin{array}{l}\text { The using of } \\
\text { tranexamic acid }\end{array}$ & aPTT value & $\begin{array}{l}\text { Total } \\
\mathbf{n}(\%)\end{array}$ \\
\cline { 2 - 3 } & $\begin{array}{l}\text { Decreasing } \\
\mathbf{n}(\%)\end{array}$ & $\begin{array}{l}\text { Not decreasing } \\
\mathbf{n}(\%)\end{array}$ & \\
\hline $\begin{array}{l}\text { Not given } \\
\text { Given }\end{array}$ & $12(26.7)$ & $33(73.3)$ & $45(100)$ \\
Total & $25(67.6)$ & $12(32.4)$ & $37(100)$ \\
\hline
\end{tabular}

aPTT: Activated partial thromboplastin time, RSUP: Rumah Sakit Umum Pusat

Table 2: Relationship between tranexamic acid therapy and the decrease of PT values among intracranial hemorrhagic patients at RSUP Fatmawati (January 2013-December 2015)

\begin{tabular}{llll}
\hline PT value & & & \\
\hline $\begin{array}{l}\text { The using of } \\
\text { tranexamic acid }\end{array}$ & $\begin{array}{l}\text { Decreasing } \\
\mathbf{n}(\%)\end{array}$ & $\begin{array}{l}\text { Not decreasing } \\
\mathbf{n}(\%)\end{array}$ & $\begin{array}{l}\text { Total } \\
\mathbf{n}(\%)\end{array}$ \\
\hline Not given & $16(5.6)$ & $29(64.4)$ & $45(100)$ \\
Given & $16(43.2)$ & $21(56.8)$ & $37(100)$ \\
Total & 32 & 50 & 82 \\
\hline
\end{tabular}

RSUP: Rumah Sakit Umum Pusat, PT: Prothrombin time

after administered of tranexamic acid was 30.27 seconds. The reference value based on the hospital laboratory results was 26.3-40.3 seconds. The mean value of the patients' initial PT was 13.32 seconds, and the PT value after administered was 13.33 seconds, while the normal reference value for PT based on the hospital laboratory results was 11.5-14.5 seconds. The increasing of PT and aPTT value in control group was $4 \%$ and $11.46 \%$. In the first group, the PT value was increase $3.2 \%$ and the aPTT value was decreased $0.9 \%$. In the second group, the PT and aPTT value was decreased $2.5 \%$ and $7.3 \%$.

The Relationship between Tranexamic Acid and aPTT and PT Values

In patients given only tranexamic acid, $67.6 \%$ demonstrated a significant decrease in aPTT values, with a significance of $0.000(\mathrm{p}<0.05)$. A total of $43.2 \%$ patients did not experience a significant decrease in PT values, with significance of 0.314. The relative risk (RR) for PT is 2.5 and for aPTT is 1.2. Patients that used tranexamic acid decreased the PT and aPTT values 2.5 times and 1.2 times greater than patients without tranexamic acid.

The Relationship between BOTH Tranexamic Acid and Vitamin $\mathrm{K}$ use and aPTT and PT Values

In patients administered a combined therapy of tranexamic acid and Vitamin K, 72.1\% demonstrated a significant decrease of aPTT
Table 3: Relationship between tranexamic acid and Vitamin $\mathrm{K}$ combined therapy and the decrease of aPTT values among intracranial hemorrhagic patients at RSUP Fatmawati (January 2013-December 2015)

\begin{tabular}{llll}
\hline aPTT value & & & \\
\hline $\begin{array}{l}\text { The using of } \\
\text { tranexamic acid }\end{array}$ & $\begin{array}{l}\text { Decreasing } \\
\mathbf{n}(\%)\end{array}$ & $\begin{array}{l}\text { Not decreasing } \\
\mathbf{n}(\%)\end{array}$ & $\begin{array}{l}\text { Total } \\
\mathbf{n}(\%)\end{array}$ \\
\hline Not given & $12(26.7)$ & $33(73.3)$ & $45(100)$ \\
Given & $31(72.1)$ & $12(27.9)$ & $43(100)$ \\
Total & 43 & 45 & 88 \\
\hline
\end{tabular}

RSUP: Rumah Sakit Umum Pusat, aPTT: Activated partial thromboplastin time

Table 4: Relationship between tranexamic acid and Vitamin K combined therapy and the decrease of PT values in intracranial hemorrhagic patients at RSUP Fatmawati (January 2013-December 2015)

\begin{tabular}{llll}
\hline PT value & & & \\
\hline $\begin{array}{l}\text { The using of } \\
\text { tranexamic acid }\end{array}$ & $\begin{array}{l}\text { Decreasing } \\
\mathbf{n}(\%)\end{array}$ & $\begin{array}{l}\text { Not decreasing } \\
\mathbf{n}(\%)\end{array}$ & $\begin{array}{l}\text { Total } \\
\mathbf{n}(\%)\end{array}$ \\
\hline Not given & $16(35.6)$ & $29(64.4)$ & $45(100)$ \\
Given & $25(58.1)$ & $18(41.9)$ & $43(100)$ \\
Total & 41 & 47 & 88 \\
\hline
\end{tabular}

PT: Prothrombin time, RSUP: Rumah Sakit Umum Pusat

Table 5: Relationship between confounding factors and significant decreases of PT and aPTT values among intracranial hemorrhagic patients at RSUP Fatmawati

\begin{tabular}{lll}
\hline Confounding factors & p of PT & p of aPTT \\
\hline Sex & 0.120 & 0.338 \\
Age & 0.120 & 0.338 \\
Comorbidities & 0.471 & 0.245 \\
Smoking habits & 0.052 & 0.238 \\
\hline
\end{tabular}

PT: Prothrombin time, RSUP: Rumah Sakit Umum Pusat, aPTT: Activated partial thromboplastin time

values, with a significance of $0.000(\mathrm{p}<0.05)$. A total of $41.9 \%$ patients also experienced a significant decrease of PT values, with a significance of $0.034(\mathrm{p}<0.05)$. The RR for PT is 2.7 and for aPTT is 1.6. Patients that used tranexamic acid decreased the PT and aPTT values 2.7 times and 1.6 times greater than patients without tranexamic acid. Relationship between tranexamic acid therapies is described in table.

The Relationship between Decreasing aPTT and PT Values and Confounding Factors

The results showed no significant relationship between sex, age, comorbidities, and smoking habits among intracranial hemorrhagic patients with decreasing PT and aPTT values.

\section{DISCUSSION}

Based on the results of this study, the male patients suffered from intracranial hemorrhaging more than female patients. Men have a greater tendency of experiencing bleeding strokes compared to women with a ratio of 2:1. Although men are more prone to suffer from such strokes at a younger age, women become more vulnerable soon after they experience menopause. Several studies have shown that hormones play an important role in this difference, which protects women from the risk of stroke until they pass through the child bearing age. Men $<65$ years of age have a greater risk of suffering intracerebral hemorrhaging at a rate about $20 \%$ higher than that of women. However, women of any age have a risk of subarachnoid hemorrhaging which is about $50 \%$ greater than that of men. According to data from 28 hospitals 
in Indonesia recorded in 2011, men suffered strokes more than women at rates of about 1.25 times greater [6].

The mean age of patients in this study is 50.18 years old. Previous study conducted in 28 hospitals in Indonesia found that the mean age of patients who had strokes was 58.8 years old [6]. The use of tranexamic acid with Vitamin $\mathrm{K}$ in intracranial hemorrhagic patients had a significantly decreased both PT and aPTT values. In contrast, patients who received only tranexamic acid without a combination of Vitamin K showed a decrease of PT values that was not significant. In the first group in which patients received only tranexamic acid, a significance value of $0.000(\mathrm{p}<0.05)$ was determined with respect to decreases of aPTT values. In that group, there was no decrease in PT values, with a significance of $0.314(\mathrm{p}>0.05)$. The second group, which included patients receiving tranexamic acid and Vitamin $\mathrm{K}$, demonstrated significant decreases in both aPTT and PT with values of 0.000 for aPTT and 0.034 for PT $(\mathrm{p}<0.05)$, respectively.

Changes in PT values means there is a problem in factor VII coagulation. Coagulation proteins that depend on the presence of Vitamin $\mathrm{K}$ synthesized in the liver include factors II, VII, IX, and X, which play important roles in hemostatic processes as procoagulants that reduce and prevent bleeding. $\mathrm{C}$ and $\mathrm{S}$ proteins also act as anticoagulants which prevent blood clotting. The main effect of Vitamin K deficiency is balancing the coagulation process by inactivating procoagulant proteins [7-9]

\section{CONCLUSION}

Patients that used tranexamic acid and Vitamin K decreased the PT and aPTT values 2,7 times and 1.6 times greater than patients without tranexamic acid and Vitamin K. Patients that used tranexamic acid decreased the PT and aPTT values 2.5 times and 1.2 times greater than patients without tranexamic acid. The combination of tranexamic acid and Vitamin $\mathrm{K}$ is potentially more effective in decreasing of PT and aPTT values in intracranial hemorrhagic. The results of this study should be followed up with subsequent research employing either a prospective cohort study or clinical testing so that there will be more evidence to support the advantages of combined tranexamic acid and Vitamin $\mathrm{K}$ therapy compared to the single administration of tranexamic acid for intracranial hemorrhagic patients.

\section{REFERENCES}

1. Kamal AH, Tefferi A, Pruthi RK. How to interpret and pursue an abnormal prothrombin time, activated partial thromboplastin time, and bleeding time in adults. Mayo Clin Proc 2007;82(7):864-73.

2. Murray D, Pennell B, Olson J. Variability of prothrombin time and activated partial thromboplastin time in the diagnosis of increased surgical bleeding. Transfusion 1999;39(1):56-2.

3. McHugh J, Holt C, O'Keeffe D. An assessment of the utility of unselected coagulation screening in general hospital practice. Blood Coagul Fibrinolysis 2011;22(2):106-9.

4. Wang Y, Wang X, Kong Y, Li F, Chen H. Retrospective analysis of the predictive effect of coagulogram on the prognosis of intracerebral hemorrhage. Acta Neurochir Suppl 2011;111:383-5.

5. Chen H, Li F, Wang X, Kong Y, Wang Y. Retrospective analysis of the predictive effect of routine biochemical results on the prognosis of intracerebral hemorrhage. Acta Neurochir Suppl 2011;111:403-6.

6. Misbach J, Ali W. Stroke in Indonesia: A first large prospective hospitalbased study of acute stroke in 28 hospitals in Indonesia. J Clin Neurosci 2001;8(3):245-9

7. Stafford DW. The vitamin K cycle. J Thromb Haemost 2005;3(8):1873-8.

8. Ferland G. The discovery of vitamin K and its clinical applications. Ann Nutr Metab 2012;61(3):213-8.

9. Tie JK, Stafford DW. Structural and functional insights into enzymes of the vitamin K cycle. J Thromb Haemost 2016;14(2):236-47. 